\title{
INDIC-NURISTANĪ SÁKTH-I/ÁN-, ĆUPTI- AND ALBANIAN SUP
}

In Indogermanica et Caucasica: Festschrift für Karl Horst Schmidt zum 65. Geburtstag, edd. R. Bielmeier and R. Stempel (Berlin: de Gruyter 1994) 38, I have reconstructed the laryngeal heteroclite ${ }_{s} V k t H / n$ ' 'thigh'. From the modern languages CDIAL adds more evidence. The basic noun is attested in Ashkun sot and Waigali $s \bar{t} t$, whereby we recognize Nuristanìs valuable contribution.

F. Sommer, Festschrift Debrunner (1954) 425-30, suggested that sakthi- 'thigh' be related to OHG scinca, OE scēanca 'crus, tibia', Dutch schonk 'bone' <*skak-thi $\mathrm{x}$ asthi 'bone'.

If we take *sákthi $<{ }^{*}{ }_{s} V^{\prime} k t-H$ as representing Bartholomae's Law, we arrive at *sákh-t $t(i)=*_{s a ́ k H-t}$, thus making Sommer's conflation otiose. Then *s $\dot{V} k-H(-t)$ implies in the terms of my 1994 argument the presence of ${ }^{*} s k-n(-g)-(\mathrm{cf} . \dot{\alpha} \sigma \tau p \alpha \dot{\gamma} \gamma \alpha \lambda \circ)^{1}{ }^{1}$ and *sk-l-, etc.

Morphologically this implies the equation(s) ${ }_{s} \dot{V} k-H(-t) \cong$ Lat. caput $<{ }^{*} k e p-H_{a}(-t)$ $\cong$ Indic yákr-t, Arm. leard.

We then may take Indic suptis, Avest. supti- (IEW 627) and their Germanic cognates to be later developments of $* k^{\prime} u p$ - $t$. The ancient paradigmatic status of this

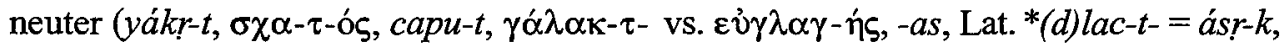
ö $\sigma \tau \rho \alpha-\kappa-o v, \stackrel{\alpha}{\alpha} \sigma \tau \alpha-\kappa$-ó $\varsigma<* H s t n-k$-ó-) [- $\alpha$ grave, -voice, -contin., + obstr.] marker is then supported in this instance by its absence in Albanian sup 'shoulder', which must be * $k$ ' $u p$ - not followed by * $t$, since the latter would have given *sut.

When we recall the $-t$ (semantically empty) suffixed to (compounded) Indo-Iranian verbal nouns, and the $-k_{\mathrm{b}}$ emptily supplied to Slavic $u$-stem adjectives (and to 'apple') and veli- 'big', 2 it sees that with this [-grave] marker we are in the presence of a piece of bleached fossil pre-IE morphology. We may also wonder about it as a source of the productive IE adjective suffix (appurtenance and participial ${ }^{3}$ ) *(s)ko-. Small languages can provide particularly precious evidence for widespread phenomena.

1 I reluctantly defer the voicing of $\gamma$ here.

2 E. P. Hamp, Journal of Slavic Studies 1. 80-2 (1993).

3 E. P. Hamp, IF 82. 77-9 (1977); 87. 73-4 (1982). 


\section{Povzetek}

INDIJSKO-NURISTANSKO SÁKTH-I/ÁN-, ĆUPTI- IN ALBANSKO sup

Rekonstruirani heteroklitski (laringal vsebujoči) samostalnik *sVktH/n- 'stegno' se prek Bartholomaejevega zakona izvaja iz ${ }^{*} b \dot{b} k-H(-t)$. Indijsko śuptis in dr. je tedaj iz starejšega $* k$ 'up- $t$, prim. albansko sup 'rama'. Verjetno imamo opraviti z okamenelim ostankom predindoevropskega oblikoslovja. 